\title{
The Development of Community-based Floating Village Tourism by Badak Liquefaction Natural Gas (A Study in Selangan City of Bontang)
}

\author{
Ruth Agnesia Sembiring ${ }^{1}$, Rita Nur Cholidha ${ }^{2}$ \\ \{nesi.biring@gmail.com ${ }^{1}$, ritakrutuk14@gmail.com ${ }^{2}$ \} \\ Universitas Brawijaya, Indonesia ${ }^{1,2}$
}

\begin{abstract}
This study discusses about the development of Kampung Selangan into a community-based tourism destination. Kampung Selangan that once developed into a tourism village is the background of this study. The Selangan City Program is expected to become a solution for the sustainable development. According to Suansri (2003), Community-Based Tourism is a tourism concept that takes environmental sustainability and sustainable tourism development aspect into account. Using qualitative descriptive method, this study tries to analyze the development process. The approach of this study is the five dimensions of Community-Based Tourism according to Suansri; economy, social, culture, environment, and politics. From each dimension, activities that support the Community-Based Tourism, e.g. trainings, new job opportunities, reduction of fish bombing, establishment of tourism awareness groups, etc. However, weaknesses such as the absence of conservation efforts directly by the community and the low initiative from the community to increase the program. Therefore, there are some basic evaluations that need to be done immediately so that the program can run well for a long time.
\end{abstract}

Keywords: Community-based Tourism, Floating Village Tourism, Badak LNG.

\section{Introduction}

Bontang is a city whose territory is mostly coastal areas and small islands. During the administration of dr. Hj. Neni Moerniaeni Sp, OG., tourism becomes the featured program. The government of the city involves private companies in the coastal areas development [1]. The partnership offered by the city government is materialized through Corporate Social Responsibility by big companies in the city. One of that major companies is PT Badak LNG. In its fourth decade, this company has high contribution to Bontang [2].

One of the areas developed into tourism destination is Kampung Selangan, inaugurated as Selangan City, in Bontang Selatan sub-district. The village covers an area of 6.600 square meters in the water area of Bontang, inhabited by 48 families. Kampung Selangan is located in Makassar Strait. Selangan has introduced its settlement areas as transit points for anyone who passes it, in the route used by tourist to go to Pulau Beras Basah. This place offers its culinary uniqueness, visitors are also presented with clear sea.

In the past, Kampung Selangan received developmental aids form PT Pupuk Kaltim in 2000s, focusing on the supporting facilities for anglers. PT Pupuk Kaltim provided net cages, boat and engine maintenance, fish seeds, and money loans. When the program ended, the community could not revitalize their net cages, they could not continue their fish cultivation 
activities. Therefore, the coastal area development must be able to create community sense of belonging to development program and sustainable development.

PT Badak LNG choses Kampung Selangan as the object of tourism development because it is located in the company's responsibility area. Selangan City is expected to become a pilot project of CSR aids and sustainable community development. It is recognized as the most organized floating village for its well-arranged buildings. The depth of the waters arounds is appropriate for the development of tourism village. Furthermore, this CSR program is also supported by PT Jotun Indonesia, which is responsible for the colorful and beautiful Kampung Selangan.

\section{Research Methods}

\subsection{Research Type and Research Method}

This qualitative research uses descriptive method to measure the development of the tourism area using the CSR from private companies, to measure the results of the development, and to analyze the economic, social, and political occurrences in Kampung Selangan.

\subsection{Research Time and Location}

This research was conducted in 30 days from March to April 2019 in Selangan City and Bontang Selatan subdistrict (the Office of Youth, Sports, and Tourism of Bontang and from PT Badak LNG).

\subsection{Research Subject}

The subjects of this study are informants who own the required data and information; officials of Youth, Sports, and Tourism Office, Bontang Health Office, Bontang Education Office, CSR department of PT Badak LNG, Bontang Lestari Village, head of $16^{\text {th }}$ neighborhood of Selangan, Pokdarwis (Tourism Awareness Group) Pelangi Pesisir of Selangan City, Indonesian Guides Association of Bontang, and netcage owner community of Selangan.

\subsection{Research Procedure}

This study uses primary and secondary data. Primary data was obtained from informants through interviews, as well as observations and records. Secondary data was obtained indirectly from library research on written literature: written documents, photos, journals, articles, books, websites, statistics, databases, and other media related to tourism development.

\subsection{Data Collection Technique}

The data was collected in three stages: interviews, observation, and documentation. The informants were selected using purposive sampling technique through determining the target informant according to the focus of the study, then gaining the access to new informants based 
on the suggestion of the previous informant. The observations were made by examining the daily activities of Selangan City's community after the CSR programs were run by PT Badak LNG: seaweed planting and processing, netcage maintenance, community service activities, visitor service activities, and people's meeting. The researcher also directly observed the communication between PT Badak LNG and the community; and between Bontang city Government and Selangan City community through the Youth, and Sport, and Tourism Office. This research documented achievement index, number of education and health facilities and infrastructure, income, population, etc.

\subsection{Data Analysis Technique}

The analysis on the qualitative data was conducted in three stages: first, data condensation includes the process of selecting, simplifying, extracting and transforming data from field notes, interview transcripts, documents, and other empirical materials. Second, data presentation covers understanding about of what happens, including deep analysis and action based on the understanding. Third, conclusion is an explicit final analysis based on data condensation and presentation.

\section{Results and Discussion}

\subsection{Community Development to Community Empowerment}

Christenson \& Robinson [3] mentioned that community development is a process in which people who live in "certain locations" develop initiatives to carry out social actions, with or without the intervention of parties outside the community, to change the economic, social, cultural, and environmental situations. In this case, intervention is not absolute; instead, the most important thing is community initiative and participation in the ongoing development process. According to the United Nations [4], community development is a process that may come from the government or from the community to improve the economic, social, and cultural conditions of powerless people, who are then empowered to create nation's progress toward integrated processes.

In line with the meaning of community development, so community empowerment must be included as the effort to increase community participate and to increase their sense of belonging to the development programs. According to Zabaeni [5], community development focuses on achieving quantitative changes as indicated by the availability of physical facilities and improvement in the level of material life. While community empowerment focuses on qualitative changes characterized by independent in thinking, behaving, and taking action and have long-term, macro, and substantive orientation. Therefore, community development is expected to encourage community empowerment as characterized by society's qualitative changes. The main objective of community empowerment is to resolve or at least reduce the impact of social problems [6][7]. The actors of the application of community development are the government, private sector, and the community itself. In this study, PT Badak LNG is the empowerment actor that provides assistance to the people of Kampung Selangan through its CSR. 


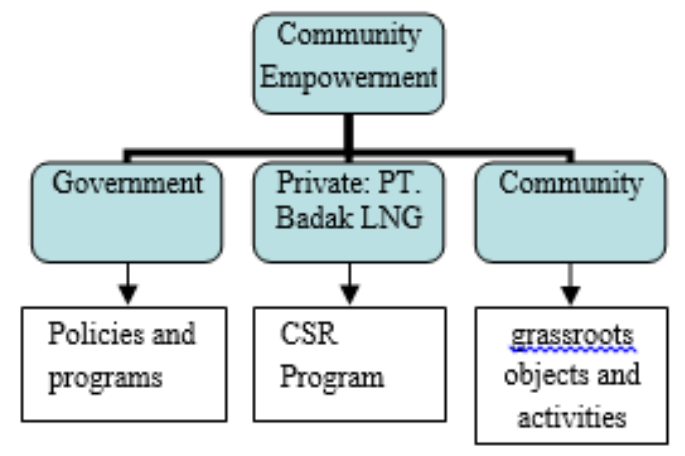

Fig. 1. The Role of Community Empowerment Actors (processed by the writer, 2019).

\subsection{The Corporate Social Responsibility of PT Badak LNG to Support the Development in Floating Village Tourism}

In the elucidation of Article $15 \mathrm{~B}$ of Law Number 25 of 2007 concerning Investment or in Indonesia, corporate social responsibility is a responsibility inherent in every investment company to create harmonious and balanced relationship according to the environment, values, norms, and culture of local people. Then Article 1 Number 3 of Law Number 40 of 2007 or in Indonesia, concerning Limited Liability Companies (UUPT), which states that social and environmental responsibility is the company's commitment to participate in a sustainable economic development to improve the quality of life and create a beneficial environment for the company itself, the local community, and the society in general.

This is reinforced by Bontang Mayor Regulation (Perwali), namely Perwali Number 36 of 2011 concerning Guidelines for the Implementation of Social and Environmental Responsibility by the Company. Then the Mayor of Bontang Decree Number 339 of 2011 concerning the Formation of the Forum for Management of Corporate Social Responsibility Planning (FMPCSR).

PT Badak LNG has given several aids to Kampung Selangan, one of which is Tekasalo Region Optimization Program (Kadere Bay, Selantuko, Selangan, and Lok Tunggul) in 2015 to empower coastal MSMEs which processing shrimp paste and dried fish in Ketambak. In the same year, PT Badak LNG also helped repair harbors and build shades for boat passengers.

In line with the plan of the Bontang government, which seeks to improve the city's tourism, PT Badak LNG took part to improve the welfare of Selangan City. Selangan City Program is run by the Community Development (Comdev) Department of PT Badak LNG. The preparation of the program had begun from mid-2017, and the program was inaugurated on 11 February 2018. The goals of PT Badak LNG with this program are as follows.

a) To maintain marine environment and water resources.

b) To give education about environment and socio-cultural preservation.

c) To renovate infrastructure in the effort of solving complex problems in Selangan. 


\subsection{The Development of Community-Based Floating Village Tourism}

Selangan City has four leading tourism potentials, namely: cage tourism, culinary tourism typical of Bontang City, mid-ocean views, and seaweed cultivation. The community is the main driver of the management and development of attractions. The community must be able to manage and recognize the natural potential that exists, maintain environmental sustainability, trying to be friendly and polite to visitors, maintain cleanliness to the ability to managerial to expertise, administration and finance.

The concept of Community-based Tourism (CBT) emerged as a concept of tourism management that prioritizes the active participation of the community with the aim of providing welfare for the community itself while maintaining and preserving the environment and maintaining local socio-cultural wisdom [8]. The understanding of CBT according to Suansri (2003) is a concept of tourism that takes into account aspects of environmental sustainability [9]. Meanwhile, another understanding of CBT is the concept of tourism that is aware of cultural, social and environmental sustainability which is then managed and owned by the community to help tourists to increase their awareness and learn about the local community way of life. Suansri conveyed five dimensions in the CBT concept, namely economic, social, cultural, environmental and political.

\subsubsection{Economic Dimension}

Economic dimensions according to Suansri [9], include the availability of funds for community development and the emergence of local community income from the tourism sector. The Floating Village Tourism development program in Selangan City is a program initiated or initiated by the Community Development Division of PT Badak LNG as a form of social responsibility or CSR. Therefore, funding for all activities of this program comes from the CSR program budget by PT Badak LNG. The amount of the budget for the implementation of the Selangan City program is approximately Rp. 297,000,000. The funding is also related to the status of PT Badak LNG which is a non-profit company so that the amount of funds used is in accordance with the amount determined by the company [10]

The results of research conducted by PT Badak LNG showed an increase in income and a decrease in the amount of expenditure of the Selangan City community since the Selangan City Program began. The following details of the economic impacts found based on Sustainability Compass: [11] There was an increase in the number of visitors in 2018 which resulted in an increase in the income of members of the Pelangi Pesisir of Rp. 500,000/month. The price of the package is Rp. 210,000/person and the average turnover obtained from the visit is Rp. 10,920,000/month. Data as of December 2018 shows that assets owned by Tourism Awareness Group are Rp. 241,344,950.

However, the increase in income was only felt by a few people who did participate directly in the development activities of the Floating Village Tourism in Selangan City, namely Pelangi Pesisir Tourism Awareness Group. Equalization of income is considered by researchers to be quite difficult to do. Opportunities for economic improvement from the existence of this program are still underestimated by some people in Kampung Selangan. 


\subsubsection{Social Dimension}

Social dimensions according to Suansri [9] include improving the quality of life, increasing community pride, equitable division of roles between men and women and young and old generations and building community organization strengthening.

The location of Selangan City which is in the middle of the sea has an influence on its people's health, especially access to emergency health conditions. Improving the quality of life through health is one of the keys so that people feel the benefits of development programs. The Bontang City Government cooperates with PT Badak LNG to provide Selangan City community health services through the Pusling (Mobile Clinic) program [11]. For health services, a Posyandu building is the location of monthly routine inspection. At the time the researchers conducted research there, the Posyandu (Maternal Clinic) was under renovation for the expansion and repair of several sides of the building. Renovating the Posyandu is also one of the activities included in the City Selangan Development Program.

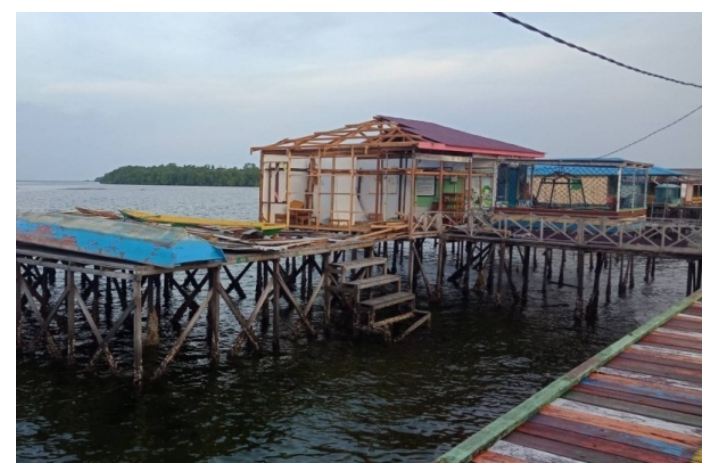

Fig. 2. Posyandu under renovation (writer's document, 2019).

In addition to the health sector, improving the quality of life also includes the education sector. Most of the people in Selangan City do not accept formal education as they should. Kampung Selangan has one Elementary School with fairly simple building conditions, namely 015 South Bontang South Elementary School. Physically, there are four classrooms with each measuring $3 \times 5$ square meters. There are also teacher and staff rooms that are separate from classrooms and are equipped with bathroom facilities. The number of elementary school age children is also very small. Sometimes even there is a grade level that has no students at all. As for the total number of teachers and staff, a total of 7 people.

Table 1. The Number of Students in 015 Selangan City Elementary School from 2016 to 2018

\begin{tabular}{clccc}
\hline \multirow{2}{*}{ No } & \multirow{2}{*}{ Year } & \multicolumn{2}{c}{ Number of Students } & \multirow{2}{*}{ Total } \\
\cline { 3 - 4 } & & Male & Female & \\
\hline 1 & 2016 & 8 & 6 & 14 \\
\hline 2 & 2017 & 8 & 7 & 15 \\
\hline 3 & 2018 & 7 & 9 & 16 \\
\hline & Source: Department of Education and Culture, 2019.
\end{tabular}

The Bontang City Education and Culture Office and PT Badak LNG made the Community Boarding Program to provide access and facilities for all Grade VI students who are in the islands and will take the final exam. All grade VI students will be recorded and 
entrusted to other elementary schools on land to conduct teaching and learning activities in the context of the preparation of the National Examination (UN) and the National Standard School Final Examination (UASBN). This was also done by two students of grade VI SDN 015 Kampung Selangan. Each of these students will be given learning facilities and stay at a homestay owned by PT Badak LNG so that these students are no longer hampered by access and get maximum test preparation. The existence of this program is also expected to help increase interest in learning so that all school-age children will continue to continue their education to secondary level.

The majority of Selangan City residents still have family relations, they believe that they are descendants of the Bajau who still survive today. The development of the era has demanded the fulfillment of more complex needs, but Kampung Selangan community continue to stay above the sea. This is a form of community pride. Their way of life then adds to the unique characteristics of the people of Selangan Village and is made a tourist attraction in the Floating Village Tourism Development Program in Selangan City.

Third, PT Badak LNG took the initiative to form a special structure that would be responsible for managing Selangan City. The structure is the Tourism Awareness Group (Pokdarwis) named the Pelangi Coastal group, whose membership comes from the Selangan City community and was formed in March 2018. The Pelangi Coastal Pokdarwis is headed directly by RT 16 treasurer Kampung Selangan. The entire Peldarwis Pelangi Coastal Board consists of six people and a number of four members. PT Badak LNG conducts training and special training for the Pelangi Coastal Pokdarwis. PT Badak LNG also monitors pokdarwis performance to determine the extent of mastery of material related to managerial and tourism. The organizational structure of Pelangi Pesisir Tourism Awareness Group is as follows:

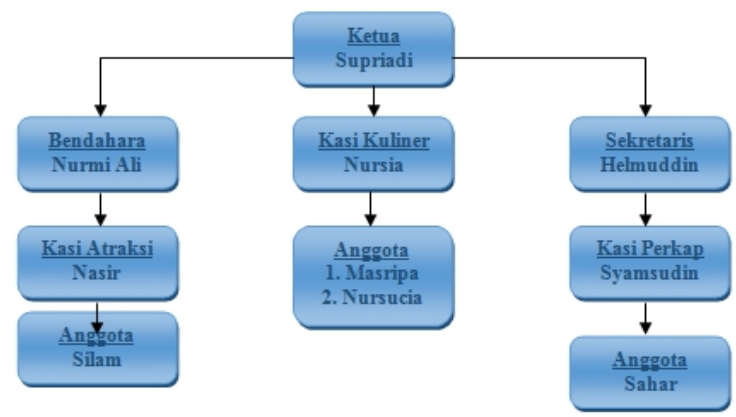

Fig. 3. Pokdarwis Pelangi Coastal Organizational Structure (File of Pelangi Coastal Pokdarwis, 2019).

Selangan City community has a division of labor to support their tourism development. When Selangan City was visited by tourists, the women were gathered by the Chairperson of Pokdarwis to provide culinary uniqueness of roasted fish and sambal Gammi [12]. The Floating Village in Selangan City is managed directly by the community through the existing Pokdarwis which does not distinguish between young and old generation. But most of the Selangan City youth prefer to continue their education or work ashore like in Bontang. There was only one young man who, and if it was related to how the youth's role in tourism management was still minimal [12]. A young man wants to participate, but does not want to be incorporated into the Pelangi Coastal Pokdarwis structure because he feels less interested. But the young man was very willing to help in mutual cooperation activities related to tourism activities. 


\subsubsection{Cultural Dimension}

Cultural dimension according to Suansri [9] includes encouragement to the community to respect cultural differences, foster cultural exchange and cultural development that is closely attached to local culture.

Selangan City community is open to various cultures that might be present [13]. Selangan City community also learn abotu various types of culture that exists in conditions to respect the tourists with a sense of openness. Even so, Selangan City community have a special limitation which absolutely cannot be broken, namely religious norms. If the different culture is contrary to the religious norms they believe in, the community will give a loud rebuke or even will reject the visit.

There was a collaboration carried out by PT Badak LNG with the Indonesian Tourism Guides Association (HPI) of Bontang City DPC through an implementation of tour guides. Selangan City has four representatives who joined the Bontang City HPI DPC. One of the cultural exchanges in this activity was when the Selangan City representatives in the Bontang City HPI DPC take part in training specifically to learn foreign languages and foreign cultures [14].

These various development activities involve the community directly from the planning process to the execution. It is an attempt to instill a strong sense of ownership of the infrastructure that they have built. At the same time introduce the culture of development to the community so that they always try to carry out development both physically and mentally.

\subsubsection{Environmental Dimension}

Environmental dimension according to Suansri [9]. includes studying the carrying capacity area, helping to regulate the disposal of waste and raising awareness about the need for conservation.

Previously the community used a cage as a place to raise fish catches that still alive so they can continue to grow to the maximum size to be sold. However, the risk is the fish seedlings from the place of cultivation need proper adaptation when transferred to cages which incidentally is natural sea water. The carrying capacity of the region is a concern of PT Badak LNG through provide ring the form of water electrolysis devices. This tool is to turn rainwater into water ready for consumption. Water electrolysis in Selangan City answered the problem of limited water consumption in settlements over the sea. Previously, the Selangan City community had to buy consumption water in gallon-sized containers.

Selangan City Program has a considerable influence in reducing waste, especially plastic waste dumped into the sea: which is more as much as $8 \mathrm{~kg} / \mathrm{week}$ [11].This reduction is helpful to prevent various marine life from the threat of plastic waste. Waste management was handed over directly to the community through the activities of the Plastic Waste Management Program which began in March 2018. Mr. Supriadi used to carry out the waste from house to house [12]. PT Badak LNG provides a garbage boat as a means of transportation to transport the rubbish. The rubbish is collected at the Temporary Disposal Site (TPS), then delivered to the Final Processing Site in the Bontang Lestari Village which is also one of the partners of PT Badak LNG.

Formerly the Selangan City community and some residents from the archipelago often used bombing techniques to get quite promising fish catches. Then the rules have been enforced for fishermen who were still carrying out these activities with legal sanctions. 
Different from coral reefs that are still a concern; the existence of mangrove forests around Selangan village is less of a concern. The Chairman of Pokdarwis said that the condition of the mangrove forests around Selangan City began to experience damage [12]. If you enter the mangrove forest area, you will find a lot of damage due to logging by local residents. Mangrove wood with a certain size is usually used as a pole to support the cage net and the need for firewood by the community. Some Selangan City communities are not yet aware of the long-term impacts of mangrove logging activities. Mangrove replanting activities are needed, especially by PT Badak LNG because PT Badak LNG also has a fostered partner in the field of mangrove seedling cultivation.

\subsubsection{Political Dimension}

Political Dimension according to Suansri [9] includes increasing the participation of local residents, increasing the power of the wider community and guaranteeing the management rights of natural resources.

Community participation as a whole still has to go through a long process. The community is enthusiastic about assistance, but there will be a sense of dependency so that it is difficult to make the community independent after the program ended. One of the reasons is the quite frequent assistance, so many of them are just waiting for help. Participation is also increasingly hampered due to dependency to local heroes without regenerate process. PT Badak made Mr. Supriadi a local hero because he is a well-known figure among Selangan City community; he was considered to have high commitment and awareness of the importance of tourism development opportunities.

Selangan City community has actually been given the widest possible space even though the Selangan City Program is purely initiated by PT Badak LNG. Community participation is considered as a form of program improvement so that the impact can be directly felt by the community and can continue to survive. There have been several examples of activities that were the result of community proposals to PT Badak LNG, e.g: proposals to add attractions to look for shells along with additional means of boots, selection of painting materials for road bridges, proposals for adding trash bins, adding drums, managerial training related to the organization and others. If the community feels that an activity will have a good impact and the community wants to commit, PT Badak LNG will collaborate with the community and the Bontang City Government to realize the activity.

Provision of space for the community has proven to be effective in building a mental for sustainable tourism development. As much as possible all forms of management of tourism resources are returned to the community and PT Badak LNG will provide the necessary facilities with various existing considerations. Communities are free to carry out management and development as long as they do not violate the applicable laws and regulations.

\section{Conclusion}

Based on the concept, Community Based Tourism can be seen from the following five dimensions: First, there is an increase in income from the tourism sector and opportunities for new jobs. Second, this program still needed the development of programs regarding health and basic education. But this program has been able to increase the level of pride and division of labor among the community. This program improves organizational skills for the community 
although it must still be focused on learning about managerial or administrative aspects. Third, there is an impetus for mutual respect and openness with new emerging cultures; the community is able to engage in cultural exchange. This program produces a development in local culture, so there is an opportunity for sustainable development. Fourth, Selangan City community has actively participated in Plastic Waste Handling activities. There is surveillance of sea bombing behavior as a way to catch fish. Fifth, presence of considerable participation among the community even though it still has to depend on the local hero. The community is also directly involved in making decisions relating to the development of the Floating Village Tourism development program in Selangan City. But, it still a needs uniformity of objectives and decisions regarding the implementation of this program.

\subsection{Recommendations}

a) PT Badak LNG as the initiator of the program must immediately schedule a mangroves conservation program and coral reefs to avoid the ecosystems effects of tourism development in the long time.

b) Pelangi Pesisir Tourism Awareness Group as the community that manages tourism must be able to invite the youth in every tourism activity.

c) Bontang City government needs to give special attentions after CRS from PT Badak LNG ended with regional regulations related to tourism levies, so the increase of tourism can influence the Regional Original Revenue of Bontang City.

\section{References}

[1] "Information and Documentation Management Officer, PPID Kota Bontang. Lokakarya Pengelolaan Pesisir Terpadu Kota Bontang," 2018.

[2] B. Sunaryo, Program Emas Badak LNG di Wilayah Pesisir, Laut, dan Pulau Terpencil. Kota Bontang: Corporate Communication Department PT Badak LNG, 2015.

[3] Soetomo, Strategi-strategi Pembangunan Masyarakat. Yogyakarta: Pustaka Pelajar, 2006.

[4] Ndhara, "Pembangunan Masyarakat: Mempersiapkan Masyarakat Tinggal Landas," Jakarta: Rineka Cipta, 1990, p. 72.

[5] A. Suhaimi, Buku Pengembangan dan Pemberdayaan Masyarakat Konsep Pembangunan Partisipatif Wilayah Pinggiran dan Desa. Yogyakarta: Dee Publish, 2016.

[6] S. Widayanti, "Pemberdayaan Masyarakat: Pendekatan Teoritis," J. Ilmu Kesejaht. Sos., vol. 1, no. 1, p. 88, 2012.

[7] C. Seftyono, M. Luthfi, A. M. Rahayu, and U. M. Alam, "Accelerating Rural Development in Central Java Indonesia: Connecting Leadership, Social Capital and Policy in Local Context," in IOP Conference Series: Earth and Environmental Science, 2018, vol. 175, no. 1.

[8] D. Kurnia and Dkk, "Pengelolaan Desa Wisata dalam Perspektif Community Based Tourism (Studi Kasus pada Desa Wisata Gubugklakah, Kecamatan Poncokusumo, Kabupaten Malang)," J. Adm. Bisnis, vol. 32, no. 02, p. 15, 2016.

[9] P. Suansri, Community Based Tourism Handbook. Thailand: REST (Responsible Ecological Social Tours) Project. 2003.

[10] The results of the interview with Ms. Reta as a representative of the PT Badak LNG Community Development Division on Thursday, March 13, 2019 at 11.09 at the Corporate Communication Office of PT Badak LNG.

[11] Paper Selangan City Community Development Division of PT Badak LNG. 2019.

[12] The results of an interview with Mr. Supriadi as Chairman of the Coastal Rainbow Pokdarwis on Friday, March 15, 2019 at 17:13 at the house of Mr. Supriadi Selangan Village.

[13] The results of the interview with Mr. Heri Kusnadi as the Chairman of the 16 Neighborhood Association (RT) of Selangan Village on Friday 22 March 2019 at 16.03 at Mr. Heri Kusnasi 
Selangan Village.

[14] The results of an interview with Mr. Zulkarnain as Chairman of the Indonesian Guides Association (HPI) Bontang City Branch on Thursday, March 21, 2019 at 17:10 at the Bontang Kuala Tourism Information Center. 